\title{
The long-term energy transition: Drivers, outcomes, and the role of the multinational enterprise
}

\section{A. Erin Bass ${ }^{1}$ and \\ Birgitte Grøgaard ${ }^{2}$}

${ }^{1}$ College of Business Administration, University of Nebraska Omaha, Mammel Hall 303L, 6708 Pine Street, Omaha, NE 68182, USA; ${ }^{2}$ Department of Strategy and Entrepreneurship, BI Norwegian Business School, Nydalsveien 37, 0484 Oslo, Norway

Correspondence:

A Erin Bass, College of Business

Administration, University of Nebraska

Omaha, Mammel Hall 303L, 6708 Pine

Street, Omaha, NE 68182, USA

e-mail: aebass@unomaha.edu

\begin{abstract}
The pre-eminence of the production and consumption of nonrenewable fossil fuels is waning with the growth of renewable energy solutions. This long-term energy (LTE) transition is one of the global grand challenges, characterized by uncertain and evolving markets. Although this is a global issue, there are regional differences and non-linear trajectories that suggest that the LTE transition is a complex challenge for firms and countries. For international business scholars, questions related to the role and effect of multinational enterprises in the context of the LTE transition have opened new avenues for advancing theoretical, managerial, and policy understanding. Thus, we advance this body of research by presenting a framework that delineates important drivers and outcomes of the transition. In this way, we emphasize how MNEs both influence and are being influenced by the LTE transition. We identify theoretical perspectives that may be useful to address LTE transition challenges, and suggest avenues for future research on this global grand challenge.
\end{abstract}

Journal of International Business Studies (2021) 52, 807-823. https://doi.org/10.1057/s41267-021-00432-3

Keywords: business and the environment; energy; global environment; multinational corporations (MNCs) and enterprises (MNEs); long-term energy transition; sustainability

\section{INTRODUCTION}

\begin{abstract}
We're at quite a unique moment where there are going to be a multitude of solutions and the question is going to be; 'which ones do you want to play in?' because there are some big opportunities and equally there are some big downside risks.
\end{abstract}

Brian Gilvary, BP former Chief Financial Officer, July 9, 2020

The global long-term energy (LTE) transition, that is, the shift away from the production and consumption of nonrenewable fossil fuels towards the use of low-carbon and renewable energy solutions, is well underway. By now, the focus has shifted from questioning if an LTE transition will take place to more nuanced debates about when and how. Indeed, there is growth of low-carbon and renewable 
energy sources across a broad range of indicators of both global energy supply and demand (IEA, 2020a; Sovacool, 2016). Despite this growth, there are regional differences and non-linear trajectories that suggest the LTE transition is an evolving, complex challenge for firms and countries. For example, declines in carbon emissions in Japan and the European Union have failed to offset the increases in China and India, and the same kind of imbalance is happening elsewhere across the globe, such that overall emissions have actually increased since the framing of the Kyoto Protocol in 1997 (Ritchie $\&$ Roser, 2020). These and other data indicate the complexity of the task, and that governments, industries, firms, and consumers across the globe grapple with this "grand challenge" (Buckley et al., 2017).

For international business (IB) scholars, questions related to the role and effect of multinational enterprises (MNEs) in the context of the LTE transition have opened new avenues for advancing theoretical, managerial, and policy understanding. To date, the IB community has paid limited attention to global energy issues despite the ubiquity of energy challenges across regions and industries. Traditional fossil fuel energy production in particular has been treated as a specific and not particularly interesting context for theory development within IB (Shapiro et al., 2018). This is surprising given the global economic impact of energy production. In Canada alone in 2019, it accounted for 219 billion Canadian dollars, $10.2 \%$ of total gross domestic product (Natural Resources Canada, 2020). Despite the limited attention to energy issues in the IB literature, two growing perspectives on MNEs and global energy challenges have emerged to provide novel understanding. One focuses on MNEs as producers of renewable energy. Research adopting this perspective investigates the strategies of MNEs to create and implement renewable energy innovations (Amankwah-Amoah, 2015; Hallbäck \& Gabrielsson, 2013; London \& Hart, 2004), as well as engage in institutional work (Lawrence et al., 2013) to improve energy accessibility (Vera \& Langlois, 2007). The second perspective focuses on MNEs as energy consumers, and, thus, their negative impacts on the environment or their attempts to improve their impacts through consuming renewable energy and low-carbon solutions. Research adopting this perspective looks at MNE strategies, such as locating where environmental standards are lax, pejoratively known as pollution havens (Eskeland \& Harrison, 2003;
Meyer, 2004) or strategies to improve environmental sustainability.

Although much of the focus of IB research on global energy challenges centers on energy consumption and production, as evidenced by these two perspectives, the LTE transition has a broader reach. What makes the LTE transition a "grand challenge" is that it involves many co-evolving, interacting components and many diverse stakeholders, and this makes progress difficult to assess (Buckley et al., 2017; S\&P Global, 2020). The current economic, social, technological, and regulatory pressures for cleaner, more sustainable energy sources create a fundamental shift towards low-carbon and renewable energy production and consumption that impacts environmental sustainability, energy security, and energy accessibility worldwide. To this end, what role might multinational enterprises (MNEs) play in the LTE transition? What might their effect be? What are the theoretical, managerial, and policy implications? To call attention to these questions and to advance IB scholarship, we present a framework that connects the two perspectives we describe above by delineating important drivers and outcomes of the transition.

We unpack the drivers and outcomes of the global LTE transition in this introduction to the Journal of International Business Studies special issue on "The LTE transition and IB", a part of "The Grand Challenge of Energy Transitions" joint initiative with the British Journal of Management. MNEs both influence and are being influenced by changes in the global economy (Cantwell et al., 2010), and we focus specifically on how they impact and are impacted by the LTE transition. In the remainder of this article, we review the various facets of our LTE transition framework in light of the challenges and opportunities it presents for MNEs. We also identify theoretical perspectives that may be useful in addressing questions raised in this special issue. We close by briefly reviewing the articles that appear in this special issue, then suggest avenues for future research on what is truly a grand challenge.

\section{THE LONG-TERM ENERGY TRANSITION: A POINT OF DEPARTURE}

Buckley et al. (2017) call on IB scholars to do more to address grand challenges by, in part, broadening their perspective and engaging with others in allied social sciences to address global phenomena of 
great import. The LTE transition is one of those, both because it is a social issue of worldwide importance and because it provides a foundation for addressing rich IB research questions. The LTE transition refers to the global shift from nonrenewable, fossil-based systems of energy generation, storage, infrastructure, and consumption - including oil, natural gas, and coal - to low-carbon solutions and renewable energy sources like wind and solar (S\&P Global, 2020). As mentioned above, the question is not if LTE transition will take place the production of various sources of renewable energy has increased over the past 50 years (see Table 1) - but rather when and how.

For MNEs, understanding the economic, social, technological and regulatory drivers of low-carbon and renewable energy solutions and how they affect LTE transition outcomes is crucial to identifying the unique challenges they face and the opportunities made available to them. Here, we draw attention to our framework as it relates to MNEs (see Figure 1). We will expand on it, paying particular attention to the drivers and outcomes of the transition, and use key facets of it to advance multiple avenues of IB theorizing.

\section{Drivers of the Long-Term Energy Transition: Interacting and Co-Evolving Components}

The LTE transition is driven by the co-evolution and interaction of economic, social, technological, and regulatory components that shape the energy system via low-carbon and renewable energy solutions. We expand on these four main drivers of the LTE transition below.

\section{Economic drivers}

The economic drivers are rooted in supply and demand. There is still demand for nonrenewable sources of energy, but there is also growing demand for low-carbon and renewable energy solutions. Two things are happening concurrently: public utilities are relying less on nonrenewable energy sources, such as coal and fossil fuels, and the capacity to generate renewable energy sources such as wind and solar is increasing (Georgallis et al., 2019; Ratinen \& Lund, 2015). Indeed, recent forecasts predict that, by 2024, the world's total renewables-based power capacity will have increased by 50\% over what it was in 2019 (IEA, 2020b; S\&P Global, 2020), and that demand for energy is expected to continue to require a mix of nonrenewable and renewable sources for years to come (see Table 1).

Increasing demand requires new and expanded infrastructure to supply low-carbon and renewable energy solutions (Akella et al., 2009). Increasing demand also creates new challenges for firms and governments making strategic decisions about energy production and consumption. Organizations such as RE100, a global initiative that brings together MNEs committed to using 100\% renewable electricity, and the Renewable Energy Buyers Alliance, an American business association of clean energy buyers, energy providers, and service providers facilitating energy transactions, have been formed by some of the world's largest MNEs, including Facebook, Google, Walmart, and General Motors, to set goals and timelines to obtain all of their power from renewable energy (S\&P Global, 2020). Meanwhile, both producers and consumers of energy must contend with a volatile, uncertain, complex, and ambiguous (VUCA) world (van Tulder et al., 2019). For IB scholars, the situation offers an ideal opportunity to examine decision-making under uncertainty, and to explore the effects of changing supply and demand on the development of markets and infrastructures.

\section{Social drivers}

Individual preferences and collective behaviors on the part of heterogeneous stakeholders, firms, consumers, and investors, may support - or hinder low-carbon and renewable energy production and consumption (Miller et al., 2013). As with other products and services, the price and reliability of supply are deciding factors in energy consumption.

Table 1 World renewable energy generation (in Terawatt-hours), 1965-2019

\begin{tabular}{|c|c|c|c|c|c|c|c|}
\hline & 1965 & 1975 & 1985 & 1995 & 2005 & 2015 & 2019 \\
\hline Hydro & 923.20 & $1,448.89$ & $1,979.77$ & $2,485.63$ & $2,916.35$ & $3,884.62$ & $4,222.21$ \\
\hline Geo Biomass & 17.99 & 34.48 & 77.79 & 146.36 & 254.59 & 538.28 & 651.81 \\
\hline Wind & 0.00 & 0.00 & 0.06 & 8.26 & 104.09 & 831.57 & $1,429.62$ \\
\hline Solar & 0.00 & 0.00 & 0.01 & 0.64 & 4.17 & 256.84 & 724.09 \\
\hline Total & 941.18 & $1,483.37$ & $2,057.64$ & $2,640.90$ & $3,279.19$ & $5,511.30$ & $7,027.73$ \\
\hline
\end{tabular}

Source: Ritchie \& Roser, 2020 
Long-term Energy Transition Framework for Multinational Enterprises

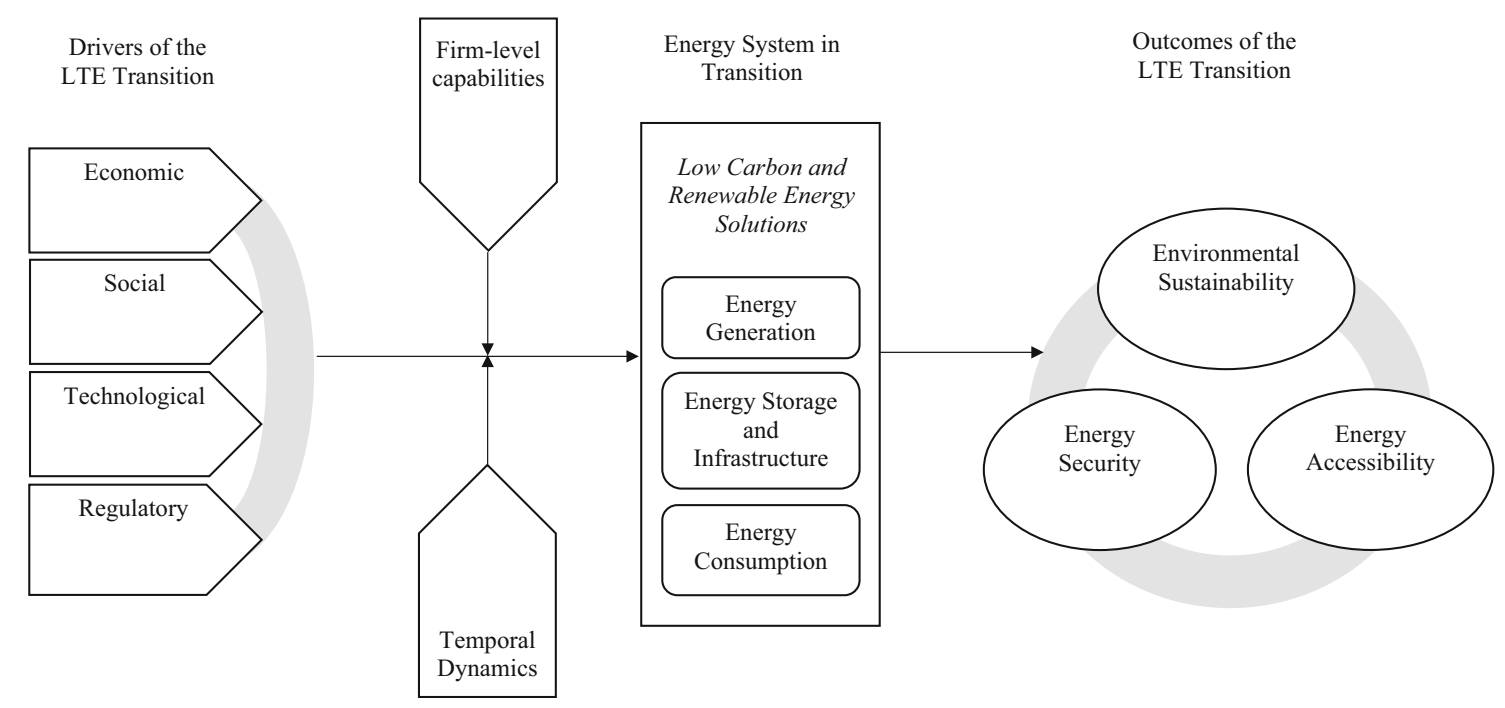

Figure 1. Long-term energy transition framework for multinational enterprises.

Yet, consumers are increasingly willing to pay a premium for low-carbon and renewable energy solutions (Kaenzig et al., 2013), and their preferences influence firm strategies. Indeed, consumer support for renewable energy in the utilities sector has facilitated the long-term strategies of producers and of MNEs in related industries (Georgallis et al., 2019; Ratinen \& Lund, 2015). In a recent global survey, $61 \%$ of the executives of large oil and gas firms responding indicated that reliance on clean fuels and renewables was fundamental to their future success (Deloitte Insights, 2020).

Reacting to social pressure for LTE transition, some investors are also backing low-carbon and renewable energy solutions. Such investors increasingly seek greater clarity about how firms are addressing long-term climate risks and opportunities. Other investors reward oil and gas producers with focused portfolios, limiting their willingness to diversify into new energy sources. This hinders energy-producing firms from transitioning to renewable energy and creates tension between them and consumers. Separately, private equity and crowd-funding investors tend to be more supportive of renewable energy strategies (Cumming et al., 2017; Marcus et al., 2013), enabling energy producers and other MNEs to diversify their energy portfolios. Some governments have also adopted more renewable energy-friendly investment strategies. For example, Norway's sovereign wealth fund, SPU, the world's largest, has a mandate to increase its investments in renewable energy infrastructure (Norges Bank, 2020), allowing it to use its oil and gas revenues to take part in a growing industry. Such is the trend towards investment in renewable energy solutions that SPU is now facing stiff competition from financial investors seeking opportunities in renewables, unexpectedly slowing its own investment growth in the sector (Hovland, 2020). In contrast, other sovereign wealth funds have continued to invest in nonrenewable energy, prioritizing the short-term interests of their home countries (Jen, 2007). Indeed, previous research on state owners highlights such differences in orientation toward short- and longterm investments (Bass \& Chakrabarty, 2014; Benito et al., 2016; Grøgaard, Colman, et al., 2019; Grøgaard, Rygh, et al., 2019). These heterogeneous preferences lead to MNEs producing and consuming a mix of both nonrenewable and renewable energy sources.

\section{Technological drivers}

Technological progress is a driver of the LTE transition, be it in the form of an advance on existing technology, a new innovation, or the diffusion of new technology across the energy system. For example, technological advances resulted in a $20 \%$ drop in the price of solar panels between 2010 and 2019 (Kelly-Detwiler, 2019). Technological drivers have also led to new ways of using existing technologies, such as the solar panels on floating offshore platforms in the Netherlands (Bellini, 2019). Some advances represent 
major breakthroughs like solid-state batteries and grid storage to improve renewable energy capture and reliability. There have also been incremental advances such as the use of smart systems employing historical and real-time data to improve efficiency in energy production and consumption (IEA, 2020c). The application of such innovations to the energy system has resulted in more efficient energy capture and storage. These and other technological developments create broader industrylevel opportunities for a range of stakeholders, including MNEs, governments, consumers, and investors, as well as firms in related industries. Thus, technological drivers go beyond idiosyncratic firm-level innovations in pushing widespread lowcarbon and renewable energy solutions across the energy system.

\section{Regulatory drivers}

While national and regional regulatory changes have proven effective in facilitating the LTE transition, their impact has been uneven. Collaborative efforts such as the Paris Climate Agreement seek to influence regulation aimed at reducing greenhouse gas emissions and, ultimately, eliminating nonrenewable energy sources. However, the Paris Climate Agreement faces two major difficulties. First, not all countries have ratified it, and among those are three large oil-exporting countries, Iran, Iraq, and Libya, while others have become either inactive or less active than others (Schiermeier, 2020). Second, among countries that have ratified the Paris Climate Agreement, progress towards achieving their goals has differed. Morocco has, for example, reformed its climate policies in order to comply with its pledge, while other countries, Argentina and Ukraine to name two, have low compliance ratings (New Climate Institute, 2020).

Given the complexity of global alignment, many countries have drafted and enacted national or regional regulations to progress the LTE transition. Nonetheless, the ability of regulators to encourage firms to increase their use of low-carbon and renewable energy solutions varies across locations (Backman et al., 2017). There are, for example, efforts underway in Europe aimed at net-zero emissions by 2050. In Asia, governments are focusing on renewable energy sources as a way to increase accessibility and sustainability, both key outcomes of the LTE transition. However, to achieve increased accessibility, regulations must first support the energy system in transition through low-carbon and renewable energy solutions. Some countries have already successfully done so. India's Central Energy Regulatory Commission is reforming the power sector via renewable energy certificate trading (Girish et al., 2015). Elsewhere there is growing political momentum for decarbonization efforts in favor of more renewable energy sources. For instance, Canada's Renewable Fuel Standard requires five percent renewable energy content in gasoline (Natural Resources Canada, 2020). Those and other initiatives increase renewable energy generation and infrastructure, and hence consumption.

Carbon taxes and government subsidies each in their own way incentivize the use of renewable energy for electricity production, resulting in opportunities for MNEs to create and capitalize on new products such as electric vehicles and offshore solar arrays. Moreover, taxes and subsidies can temporarily increase predictability for production and consumption of low-carbon and renewable energy solutions. This may be important for firms considering large capital investments in markets under development. For MNEs, choices about where to operate are made more complex as a result of different regulatory environments. MNEs operating in multiple geographies may therefore benefit from more flexible regulations such as performance-based rate-making, time-of-use pricing, green tariffs, rate recovery for electric vehicle infrastructure investment, and the setting up of markets for distributed energy resources (Zinaman et al., 2015). Thus, regulatory mandates, including policy incentives, are crucial to LTE transition, as how they are implemented, as well as the timing of implementation, is of considerable concern to MNEs.

\section{Co-evolving and interacting drivers}

Although each of the four categories of drivers impacts the LTE transition on its own, interaction between them is also important. As we have seen, consumer preference for cleaner energy, a social driver, has increased demand for renewable energy, an economic driver, thereby creating opportunities for MNEs. By the same token, increased demand for renewable energy has pushed established MNEs and new entrants alike to develop and use new technologies to produce and store energy from renewable energy sources, a technological driver, and geographic differences in technological advances and institutional support, a regulatory driver, influences the location choices of MNEs. Thus, the co-evolving and interactive nature of the 
drivers, as well as critical interfaces between new and existing energy systems, create challenges and opportunities for MNEs as energy producers or consumers, or indeed as both. The complexities that arise cannot be grasped without understanding two additional elements that might influence their co-evolution and interaction, namely, temporal dynamics and firm-level capabilities.

\section{Additional Considerations: Temporal Dynamics and Firm-Level Capabilities}

\section{Temporal dynamics}

"Energy transitions are long, protracted affairs, taking decades to unfold" (Sovacool, 2016: 2). With its technological challenges, and those related to developing the ability to scale low-carbon and renewable energy solutions across industries and geographies, there is likely to be a requirement for a nonrenewable and renewable energy mix. For some MNEs, this will require balancing the ongoing profit-generating production or consumption of nonrenewables with the development of new markets and business models for the production and consumption of renewable energy, and this balancing act is likely to change over time. To this end, if we were to conceptualize the LTE transition as one occurring in phases (Sovacool, 2016), it would look like a sequence of many small simultaneous changes followed by periods of relative stagnation. The MNE may balance its energy mix of nonrenewables and renewables differently across these phases. As an added complexity, each country and region moves on its own LTE transition timeline. It is important that MNEs understand at what stage a country is in its LTE transition, recognizing that operating in multiple countries may also mean operating in multiple phases of the LTE transition.

\section{Firm-level capabilities}

The relationship between the drivers and the energy system in transition is also influenced by firm-level capabilities. These, and new business models, are crucial if a firm is to successfully enter and operate in this shifting energy industry. MNEs must be capable of scaling-up activities, and of identifying and acting on new market opportunities related to low-carbon and renewable energy generation, storage, infrastructure, and consumption. Changes to the global energy landscape have also opened opportunities for new entrants, such as Microsoft and Google, with firm-level capabilities in digitalization and machine-learning. Other firms have sought to transfer their capabilities in nonrenewables to opportunities offered in low-carbon and renewable energy. Ørsted, a Danish incumbent, has divested its carbon-intensive assets and now focuses just on deploying its capabilities for renewable energy (Ørsted, 2020). Many oil and gas producers have developed dynamic capabilities from years of experience with VUCA markets and diverse resource plays (Feiler \& Teece, 2014; Shuen et al., 2014). Those capabilities may be highly valuable for developing some low-carbon solutions, e.g., carbon capture and storage, and specific renewable sources, e.g., transferring capabilities from offshore oil and gas projects to offshore wind. However, the capabilities of these large oil and gas producers may not be as readily transferable in other cases, such as in solar energy.

Most markets for renewable energy are growing rapidly. This creates entrepreneurial opportunities for innovative and agile firms. However, scaling-up low-carbon and renewable energy solutions also requires manufacturing capacity, industrial capabilities, and financial resources. Hence, heterogeneous market actors are needed. Rapid industry growth also creates opportunities for new, at times unconventional, collaborations. For example, Facebook, as a large global consumer of energy, has committed to reaching 100\% use of renewables by 2020, and to that end has invested directly in a solar project, while also doing joint research on renewable energy storage (IEEFA, 2019; Shead, 2020). Microsoft, another large energy consumer, is contributing its digital skills to a project with three oil and gas MNEs that seeks to develop a new business ecosystem for transporting and storing captured $\mathrm{CO}_{2}$ from large industrial emitters (Heikell, 2020). This will allow Microsoft to reach its own sustainability goals while also contributing to the new $\mathrm{CO}_{2}$ storage industry. These Facebook and Microsoft examples show how some large energy consumers are developing capabilities to reduce their carbon footprints. In sum, the development of firm-level capabilities to support the LTE transition can occur within energy incumbents, among new entrants - start-ups or firms from adjacent industries, or through collaboration between firms, research institutions, and governments - connecting multiple, diverse actors in a new business ecosystem. 


\section{MEASURING PROGRESS: OUTCOMES OF THE LONG-TERM ENERGY TRANSITION}

As we have explained in detail above, there are four co-evolving and interacting drivers of the LTE transition, and temporal dynamics and firm-level capabilities play a role in facilitating progress towards it. Low-carbon and renewable energy solutions contribute to three main outcomes: environmental sustainability, energy security, and energy accessibility. Although much of the focus of the LTE transition is on environmental sustainability, the other two outcomes are also important. We explore all three of them next.

\section{Environmental Sustainability}

Environmental sustainability will be the ultimate outcome of the LTE transition and, as such it receives the most attention from the media - and from researchers. Progress towards it is measured by improved environmental sustainability, that is, the ability to meet current needs without compromising those of future generations (Kuhlman \& Farrington, 2010). Thus, progress is often measured by reduction in energy-related greenhouse gas emissions as a result of various forms of decarbonization during energy generation. Measures of environmental sustainability include carbon emissions, carbon intensity, electrification, energy intensity, and clean energy investment (IEA, 2020a).

Each country and region moves according to its own LTE transition timeline. The result is that there are differences in the mix of nonrenewable and renewable energy consumed, and thereby in carbon emissions and carbon intensity, higher values of which are linked to lower environmental sustainability. Broadly, global carbon emissions rose from 24.26 billion tons in 1997 to 35.82 billion in 2017 (Ritchie \& Roser, 2020). A more nuanced picture is painted by regional carbon emissions: those of the US declining by $7.5 \%$ and of the EU by $18.7 \%$ over the last three decades, during which time those of China and India increased by $188.6 \%$ and $168.9 \%$, respectively.

MNEs that can capitalize on such differences may be able to develop competitive advantages by translating the experience gained in more environmentally sustainable countries to those that have yet to achieve the same levels of sustainability. For example, Eavor, a Canadian geothermal firm, chose Germany as the place to commercialize its EavorLoop $^{\mathrm{TM}}$ technology, which generates geothermal energy by circulating fluid through a massive subsurface radiator (Eavor, 2020). German culture and regulations made it an ideal setting for Eavor to improve its technology, contributing to higher environmental sustainability indicators for the country. The firm can now introduce its technology in other countries, improving sustainability in them as well.

\section{Energy Security}

The onset of new energy infrastructures and technologies often has significant implications for the security of energy systems (Finley, 2019). By energy security, we mean safeguarding against attacks, instabilities, and manipulations to energy supply and sources, for example, through the targeting of facilities by terrorists, civil unrest, and political hostility (Finley, 2019). The existing policies and regulatory frameworks that have been designed to protect the reliability of nonrenewable energy supplies can also be extended to protect renewable energy supplies. Oil and gas facilities in Colombia, Russia, and other countries have been attacked, and one would expect renewable energy infrastructures to be subject to similar threats, especially in countries where known terrorist groups are active and where foreign investors have significant interests (Stegen et al., 2012). Energy-producing MNEs of all kinds must consider the implications of that reality and how they affect the ability to deliver energy securely.

In addition to the kinds of threats we list above, the LTE transition creates new vulnerabilities and risks, such as global supply chain instability and cyber attacks on the energy infrastructure. Military conflict and labor action are destabilizing events that are likely to negatively impact global supply chains, and thereby an MNE's ability to produce or consume renewable energy. While power from renewable energy may be domestically produced, supply chain inputs are frequently from abroad, and component production is often concentrated in a given geographical location. Consider China's dominance in the global generation of solar power panels and batteries for electric vehicles (Zeng et al., 2015). Political or economic instability in China could threaten MNE access to these crucial inputs, and thus the ability to provide energy reliably. Technological advances such as digitalization augment security concerns for MNEs using cyber technologies. The interdependence between the physical and the cyber infrastructures used by these MNEs create cyber-attack vulnerabilies that range from billing fraud to system override and physical damage (Bailey et al., 2020). Future research could 
address the kinds of threats faced by MNEs producing and consuming renewable energy.

\section{Energy Accessibility}

Nearly a billion people worldwide live without access to energy (World Bank, 2020). Sources of nonrenewable energy are not evenly distributed throughout the globe, with countries rich in nonrenewables, such as Canada, the US, Saudi Arabia, and Russia, enjoying more energy accessibility. This assures reliable sources of energy for MNEs operating in such resource-rich countries, and, when paired with supportive regulation and economic stability, it often means high standards of living (World Bank, 2020). Predictably then, energy accessibility has frequently been the cause of geopolitical tensions as the governments of countries that have an abundance of resources seek to protect them (Bass \& Chakrabarty, 2014). At the local level, greater energy accessibility makes for communities with high-quality jobs, well-developed physical infrastructures, and solid economic development. Clearly, not all countries have similar energy access. The disparity between energy "haves" and "have-nots" is at the crux of the energy accessibility issue.

Thus, the LTE transition represents a crossroads in which existing energy accessibility issues can be replicated or remedied. Some MNEs have recognized the opportunities for improving access to renewable energy sources, especially for emerging economies and low-income communities (Doh, 2019). Indeed, some countries and communities poor in nonrenewable resources may well be rich in renewable ones, such as wind and solar. The advantages available to those already having an abundance of energy will accrue to those who currently lack it-high-quality jobs and expanding business opportunities among them (Sovacool \& Drupady, 2016). MNEs entering countries with insufficient energy accessibility could facilitate positive LTE transition outcomes in at least two ways. First, they can invest in localized renewable energy solutions, such as solar panel installations. Where property rights make such solutions difficult, solar community gardens might be the answer, and, for rural areas, there are off-grid options (Burke et al., 2019). Second, MNEs can partner with local firms, non-profits, and governments to co-develop renewable energy solutions (Ramirez, 2021). In that case, MNEs can leverage their knowledge and capabilities to "augment the skills-base, bridge any gaps, and gain complementarities" (Shakeel et al., 2017: 856).

\section{THEORETICAL APPROACHES TO UNDERSTANDING THE MULTINATIONAL ENTERPRISE AND THE LONG-TERM ENERGY TRANSITION}

We have focused up to this point on our LTE transition framework (see Figure 1), paying particular attention to drivers and outcomes. The LTE transition is a rich context for the development of new insights into extant MNE theory. We look now at five theoretical approaches, each of which addresses in some way our original questions about how MNEs both influence and are being influenced by the LTE transition (see Table 2). We begin with New Internalization Theory, as several contributions to this special issue show its promise for generating novel insights into global grand challenges such as the LTE transition.

\section{New Internalization Theory}

Internalization theory is perhaps the most dominant theoretical framework for studying MNEs (Narula et al., 2019). The strand referred to as New Internalization Theory sees MNE strategies and performance as shaped by both firm-specific advantages (FSAs) and country-specific advantages (CSAs). The LTE transition is changing the nature of CSAs. Size, quality, and ease of access to natural resources are the main CSAs for MNEs producing nonrenewable energy, such as oil and gas. The key concerns of such MNEs are the risks associated with resource exploration and development, operational safety, and stakeholder management of aboveground risks, and the costs, efficiency, and transferability of technology across locations, e.g., hydraulic fracturing technology. In contrast, lowcarbon and nonrenewable energy sources are evolving amid significant institutional uncertainty and market risk. Countries that offer some predicability and advantages related to economic, social, technological, and regulatory drivers create new types of CSAs.

FSA recombination - new and novel ways of using FSAs - is a central concept within New Internalization Theory. Recombination can take multiple paths involving FSAs that are geographically spread across an MNE, or even external to it, but nonetheless complementary (Rugman \& Verbeke, 2001). For instance, producers of carbonintensive energy would be expected to leverage 
Table 2. Theoretical approaches to understanding the multinational enterprise in the long-term energy transition

\begin{tabular}{|c|c|c|c|}
\hline $\begin{array}{l}\text { Theoretical } \\
\text { perspective }\end{array}$ & $\begin{array}{l}\text { Key assumptions relevant to the LTE } \\
\text { transition }\end{array}$ & Sample research questions & $\begin{array}{l}\text { Relevant articles from the IB } \\
\text { literature }\end{array}$ \\
\hline $\begin{array}{l}\text { New } \\
\text { Internalization } \\
\text { Theory }\end{array}$ & $\begin{array}{l}\text { CSAs are central to the LTE transition, } \\
\text { and the LTE transition reveals CSA } \\
\text { interdependencies. The FSA/CSA } \\
\text { framework can serve as a } \\
\text { conceptualization of MNE changes } \\
\text { and the critical role of FSA } \\
\text { recombination in the LTE transition. } \\
\text { The LTE transition brings into focus } \\
\text { FSA recombination using internal } \\
\text { and external complementary } \\
\text { resources. }\end{array}$ & $\begin{array}{l}\text { How does the LTE transition shape } \\
\text { FSAs, CSAs, and FSA } \\
\text { recombination? What } \\
\text { opportunities exist for FSA } \\
\text { recombination through new types } \\
\text { of partnerships? }\end{array}$ & $\begin{array}{l}\text { Narula et al. (2019) and Verbeke } \\
\text { and Kano (2016) }\end{array}$ \\
\hline $\begin{array}{l}\text { Resource } \\
\text { Dependence } \\
\text { Theory }\end{array}$ & $\begin{array}{l}\text { The availability and accessibility of } \\
\text { both nonrenewable and renewable } \\
\text { energy create interdependencies } \\
\text { between countries and MNEs. }\end{array}$ & $\begin{array}{l}\text { How do power dynamics and } \\
\text { interdependencies shift as } \\
\text { nonrenewables are supplanted by } \\
\text { low-carbon and renewable energy } \\
\text { solutions? }\end{array}$ & $\begin{array}{l}\text { Bass and Chakrabarty, (2014); } \\
\text { Cuervo-Cazurra and Li (2020) } \\
\text { and Mohr et al. (2016) }\end{array}$ \\
\hline $\begin{array}{l}\text { Institutional } \\
\text { Theory }\end{array}$ & $\begin{array}{l}\text { Institutional strengths or weaknesses } \\
\text { create opportunities for MNEs in } \\
\text { both home and host countries. } \\
\text { MNEs may be affected differently by } \\
\text { host-country institutions as they } \\
\text { operate in multiple institutional } \\
\text { environments. }\end{array}$ & $\begin{array}{l}\text { What are the institutional } \\
\text { complexities created by the LTE } \\
\text { transition? How do MNEs operate } \\
\text { across institutional environments } \\
\text { and how does this help or hinder } \\
\text { progress in the LTE transition? }\end{array}$ & $\begin{array}{l}\text { de Lange, (2016), Doh (2019) } \\
\text { and Mbalyohere et al. (2017) }\end{array}$ \\
\hline $\begin{array}{l}\text { Stakeholder } \\
\text { Theory }\end{array}$ & $\begin{array}{l}\text { MNEs must manage diverse } \\
\text { stakeholders across geographic } \\
\text { locations that have varying } \\
\text { stakeholder support for the LTE } \\
\text { transition. }\end{array}$ & $\begin{array}{l}\text { What are the motivations of various } \\
\text { stakeholders of the LTE transition? } \\
\text { Do MNEs adopt similar LTE } \\
\text { transition strategies across } \\
\text { geographic locations despite } \\
\text { facing differing stakeholder } \\
\text { pressures? }\end{array}$ & $\begin{array}{l}\text { Crilly (2011), Devinney et al. } \\
\text { (2013) and Park et al. (2014) }\end{array}$ \\
\hline $\begin{array}{l}\text { Dynamic } \\
\text { Capabilities }\end{array}$ & $\begin{array}{l}\text { The LTE transition involves global } \\
\text { change from one type of energy to } \\
\text { another. MNEs must develop } \\
\text { capabilities to adapt to this change } \\
\text { and to deploy them across } \\
\text { geographic locations. }\end{array}$ & $\begin{array}{l}\text { How can MNEs adapt to changes } \\
\text { inherent in the LTE transition? What } \\
\text { types of dynamic capabilities are } \\
\text { central to firms operating in the LTE } \\
\text { transition? }\end{array}$ & $\begin{array}{l}\text { Grøgaard, Colman, et al. (2019), } \\
\text { Grøgaard, Rygh, et al. (2019)), } \\
\text { Luo (2000), Riviere et al. } \\
\text { (2020) and Teece (2014) }\end{array}$ \\
\hline
\end{tabular}

current strengths when attempting to enter lowcarbon or renewable energy generation markets. Proof of this is that companies such as Equinor and $\mathrm{BP}$ are investing in offshore wind projects where they can leverage their experience in offshore oil and gas activities (e.g., Equinor's Hywind Scotland and Dogger Bank wind projects offshore the UK, and joint Empire Wind and Beacon Wind projects offshore New York and Massachusetts). There have been calls for more attention to be paid to the complexities of FSA recombination (Grøgaard et al. 2019a, b; Verbeke \& Kano, 2016), and the LTE transition provides an interesting research context to study FSAs, CSAs, and recombination, as well as opportunities to study FSA recombination through new types of partnerships.

\section{Resource Dependence Theory}

Resource Dependence Theory is a useful lens through which to examine resource security (Bass \& Chakrabarty, 2014), dependence on new technology (Dunford, 1987), and the new network interdependencies created by the LTE transition (Rossignoli \& Lionzo, 2018). In contrast to New Internalization Theory in which FSAs and CSAs determine MNE strategic choices and performance, Resource Dependence Theory stresses the interdependence of MNEs and governments, as well as the power dynamics and resource-seeking motives of 
diverse actors (Cuervo-Cazurra \& Li, 2020; Mohr et al., 2016). China serves as a good example, in that historically it has relied on imported nonrenewable energy inputs (World Bank, 2020), but now, as one of the world's leading manufacturers of lithium-ion batteries, is an energy source exporter in the burgeoning market for electric vehicles (Zeng et al., 2015). Research on the ramifications of a shift in dependency of that kind could benefit from adopting a resource dependence perspective. How does such a shift blur the lines between competing MNEs, or between MNEs and governments? Just as MNEs are seeking positions in the renewable energy market, so are state-owned enterprises. Solar module manufacturers like Jinko Solar of China or SunPower of the US also compete with a firm like Hevel of Russia, which is partially governmentowned (Boute \& Zhikharev, 2019). Resource Dependence Theory can provide novel insights into how the LTE transition shifts power dynamics and interdependencies for MNEs and governments as nonrenewables are supplanted by low-carbon and renewable energy solutions.

\section{Institutional Theory}

The LTE transition shows how institutions affect firm-level decisions. The diversity of regulations, their multi-level structure, and the large number of market actors is fertile ground for advancing Institutional Theory. While New Internalization Theory, as we discuss above, treats institutions as CSAs, the various strands of Institutional Theory view institutions as processes, frames, practices, or logics that guide MNE behavior and describe how MNEs work to influence them. Indeed, the LTE transition not only illuminates international institutional differences due to government policies and infrastructure but also reveals how MNEs can take advantage of them, similar to how MNEs overcame difficulties caused by weak financial institutions by entering emerging emerging markets with mobile financial technologies (Amankwah-Amoah et al., 2019; Onsongo, 2019). In this way, Institutional Theory is useful to investigate how MNEs might bring renewable energy solutions to markets with weak energy system structures (de Lange, 2016; Mbalyohere et al., 2017). Thus, Institutional Theory can shed light on institutional complexities created by the LTE transition and how MNEs operate in multiple institutional settings to help or hinder progress in the LTE transition.

\section{Stakeholder Theory}

The interconnections of stakeholders within the LTE transition provides fertile ground for theorizing. Stakeholder Theory centers on how organizations create value for a broad range of stakeholders, including local communities, customers, suppliers, governments, and shareholders (Crilly, 2011; Devinney et al., 2013; Freeman, 1984). In contrast to New Internalization Theory, which holds that firms develop capabilities for managing specific stakeholders, such as regulators (Rugman \& Verbeke, 1998), Stakeholder Theory looks at the various strategies that MNEs use to meet stakeholder needs. Stakeholder Theory thus captures the heterogeneity of stakeholder interests in the LTE transition, and addresses the significant pressure placed on MNEs to adopt renewable energy sources and reduce emissions. Recent research shows that non-market stakeholders are also able in some cases to compel market actors to undertake projects that further the LTE transition (Verbeke et al., 2017). For example, environmental policy advocates in Europe have pressured governments to impose strict limits on greenhouse gas emissions and to pursue ambitious carbon reduction policies which MNEs must follow (Park et al., 2014). MNEs operating in countries with green party political representation, as is the case in Canada, France, and Germany, are likely to be subject to stronger renewable energy mandates than those operating in countries with little or no green party political representation, as evidenced in the article by Hartmann, Inkpen, and Ramaswamy in this special issue. Thus, diverse stakeholders ranging from shareholders and consumers to public policymakers and NGOs have a fundamental influence on MNE strategies. Research using Stakeholder Theory can uncover the motivations of various stakeholders with interests in LTE transition and investigate how the different stakeholder pressures MNEs face across countries affect their LTE transition strategies.

\section{Dynamic Capabilities}

The Dynamic Capabilities literature looks at how MNEs adapt to changing business environments (Luo, 2000; Teece, 2014) and complements New Internalization Theory. While both focus on MNE advantages, Dynamic Capabilities Theory suggests that MNEs can achieve competitive advantage if they can concurrently develop and deploy capabilities for adapting to a changing global landscape (Grøgaard et al. 2019a, b; Riviere et al., 2020). Given that the LTE transition represents a global 
shift from nonrenewable sources of energy to lowcarbon and renewable energy solutions, understanding how MNEs develop and deploy capabilities is an important part of the puzzle. Capabilities that allow MNEs to make major operational and/or technological adaptations and adjust to international regulatory differences are core to the LTE transition. Island Green Power, a UK MNE, serves as a good example. It has been able to develop largescale "utility-size" solar plants inside the UK, and also in Australia, Ireland, Italy, and Spain, by tapping into strong government and consumer support for renewable energy (Island Green Power, 2021). Dynamic Capability theorizing can advance our understanding of how energy producers, such as large oil and gas MNEs, are now moving into low-carbon and renewable energy solutions, but are still reliant on garnering sufficient revenues from carbon-intensive activities to fund their progress. In sum, the Dynamic Capabilities perspective can be useful to investigate how MNEs adapt to the changes inherent in the LTE transition, and what types of dynamic capabilities are central to firms to successfully transition to low-carbon and renewable energy solutions.

\section{CONTRIBUTIONS TO THE SPECIAL ISSUE}

The six articles included in this special issue highlight the various roles MNEs play in the LTE transition, focusing on challenges facing energy producers (Georgallis, Albino-Pimentel \& Kondratenko; Patala, Juntunen, Lundan \& Titvala), energy consumers (Nippa, Patnaik \& Taussig), or a broad range of actors across energy value chain activities (Hartmann, Inkpen \& Ramaswamy; Bohnsack, Ciulli \& Kolk; Doh, Budhwar \& Wood).

We discuss here how these contributions relate to our conceptual framework of the LTE transition. Every article covers multiple elements of the conceptual framework, thereby illustrating the complexities and interdependencies of the LTE transition. They also illustrate that we need a broad methodological approach to tackle the challenging research questions posed by the LTE transition. We give very brief summaries of the articles in Table 3, pointing out the specific facets of the LTE transition with which each deals. We also examine the contributions made to IB theory and to our understanding of the role of the MNE in the LTE transition.

Drivers of the LTE transition are discussed in all the articles, with some using regulatory drivers as a research context to uncover MNE-level adaptations. For example, Nippa et al. examine the response of firms affected by EU emissions regulations, and Bohnsack et al. use the rapidly evolving solar industry to examine business model adaptations. All six articles include discussion of the central role regulations play and some aspect of their impact on MNEs, while also highlighting the importance of firm-government interdependencies (Doh et al.). For example, in their study of the European solar energy industry, Georgallis et al. illustrate how regulations influence the location choices of MNEs, and Bohnsack et al. examine how changes in regulation influence investments in renewables and the role of FSAs. However, as we write above, regulations vary significantly across countries and can therefore be difficult to quantify and compare. The contributors to this special issue offer suggestions to address this. In their study of the global oil and gas industry, Hartmann et al. propose finding proxies for drivers that are difficult to quantify, i.e., using the relative strength of green political parties to measure social drivers. Other authors have facilitated comparison by narrowing their geographic scope to a specific region, such as the EU. Indeed, the EU offers a fruitful context for the study of regulatory drivers from a multilevel perspective as MNEs must contend with both EU and nationallevel regulations (Nippa et al.).

Firm-level capabilities also influence MNE strategies and investments for low-carbon and renewable energy solutions. Some contributors to this special issue underscore the importance of specific capabilities (Bohnsack et al.; Patala et al.), others of experience (Hartmann et al.; Georgallis et al), and finally of governance (Nippa et al.), highlighting the interplay of FSAs and CSAs. Other FSA-like experiences with low-carbon solutions, renewables, and government regulations are flagged as having influence on perceived threats and opportunities of LTE transition drivers. The message is clear in several of the contributions: foreign direct investments are crucial if energy production and consumption are to be scaled-up and the LTE transition is to succeed. Thus, energy-producing MNEs play a particularly important role in facilitating the transition.

In line with the extant literature, the LTE transition outcome receiving the most attention in this special issue is environmental sustainability. This is in part a reflection of the emphasis on emission levels in the Paris Climate Agreement and of the climate debate in general. It also illustrates that the 
Table 3. Summary of articles

\begin{tabular}{|c|c|c|c|c|c|}
\hline Authors & Title & Research question & $\begin{array}{l}\text { How the article } \\
\text { relates to the LTE } \\
\text { transition } \\
\text { framework } \\
\text { (Figure 1) }\end{array}$ & Data source(s) & $\begin{array}{l}\text { How the article } \\
\text { contributes to research } \\
\text { on the LTE transition }\end{array}$ \\
\hline $\begin{array}{l}\text { Bohnsack, } \\
\text { Ciulli \& Kolk }\end{array}$ & $\begin{array}{l}\text { The role of business } \\
\text { models in firm } \\
\text { internationalization: An } \\
\text { exploration of European } \\
\text { electricity firms in the } \\
\text { context of the energy } \\
\text { transition }\end{array}$ & $\begin{array}{l}\text { What is the role of } \\
\text { business model- } \\
\text { related specific } \\
\text { advantages (BMSAs) } \\
\text { in the } \\
\text { internationalization of } \\
\text { firms? }\end{array}$ & $\begin{array}{l}\text { Conceptualizes } \\
\text { business models } \\
\text { as FSAs } \\
\text { Shows how } \\
\text { MNE decisions } \\
\text { contribute to } \\
\text { investments } \\
\text { into renewable } \\
\text { energy } \\
\text { solutions }\end{array}$ & $\begin{array}{l}\text { Multiple case studies } \\
\text { in the electricity } \\
\text { industry in the } \\
\text { European Union }\end{array}$ & $\begin{array}{l}\text { Shows the LTE transition } \\
\text { is a fruitful context for } \\
\text { studying key challenges } \\
\text { within the IB literature } \\
\text { Identifies the need for a } \\
\text { systemic view of firm- } \\
\text { level competitiveness } \\
\text { Explains how LTE } \\
\text { drivers influence the } \\
\text { extent to which FSA } \\
\text { recombination is } \\
\text { possible } \\
\text { Shows new } \\
\text { internationalization } \\
\text { patterns that emerge } \\
\text { in the complex } \\
\text { context of the LTE } \\
\text { transition }\end{array}$ \\
\hline $\begin{array}{l}\text { Georgallis, } \\
\text { Albino- } \\
\text { Pimentel \& } \\
\text { Kondratenko }\end{array}$ & $\begin{array}{l}\text { Jurisdiction shopping } \\
\text { and foreign location } \\
\text { choice: The role of } \\
\text { market and nonmarket } \\
\text { experience in the } \\
\text { European solar energy } \\
\text { industry }\end{array}$ & $\begin{array}{l}\text { How do government } \\
\text { policies of support to } \\
\text { industry affect foreign } \\
\text { investment location } \\
\text { choices? }\end{array}$ & $\begin{array}{l}\text { Discusses } \\
\text { regulatory } \\
\text { drivers } \\
\text { Discusses firm } \\
\text { market and } \\
\text { non-market } \\
\text { experience } \\
\text { Analyzes } \\
\text { renewable } \\
\text { energy } \\
\text { investment } \\
\text { location choice }\end{array}$ & $\begin{array}{l}\text { Foreign greenfield } \\
\text { investments in the } \\
\text { solar energy industry } \\
\text { by EU firms into } \\
\text { other EU countries }\end{array}$ & $\begin{array}{l}\text { Highlights the positive } \\
\text { role of government } \\
\text { regulation intended to } \\
\text { support the LTE } \\
\text { transition } \\
\text { Shows how regulatory } \\
\text { frameworks affect } \\
\text { firms heterogeneously, } \\
\text { depending on firm } \\
\text { experience, especially } \\
\text { non-market } \\
\text { experience } \\
\text { Applies bounded } \\
\text { reliability to the } \\
\text { governmental sphere }\end{array}$ \\
\hline $\begin{array}{l}\text { Hartmann, } \\
\text { Inkpen \& } \\
\text { Ramaswamy }\end{array}$ & $\begin{array}{l}\text { Different shades of } \\
\text { green: Global oil and } \\
\text { gas companies and } \\
\text { renewable energy }\end{array}$ & $\begin{array}{l}\text { Why are some firms } \\
\text { committed to } \\
\text { renewable energy } \\
\text { while others are not? }\end{array}$ & $\begin{array}{l}\text { Discusses social } \\
\text { and regulatory } \\
\text { drivers } \\
\text { Shows how firm- } \\
\text { level } \\
\text { experience } \\
\text { leads to } \\
\text { investment in } \\
\text { renewable } \\
\text { energy }\end{array}$ & $\begin{array}{l}90 \text { oil and gas } \\
\text { companies identified } \\
\text { through S\&P Global } \\
\text { Platts ranking of the } \\
\text { world's largest } \\
\text { energy companies }\end{array}$ & $\begin{array}{l}\text { Shows how social } \\
\text { pressure for good } \\
\text { environmental } \\
\text { performance is a key } \\
\text { driver of investment } \\
\text { Argues that incentives } \\
\text { are as important as } \\
\text { penalties } \\
\text { Emphasizes the role } \\
\text { played by firm } \\
\text { capabilities, and also } \\
\text { the importance of the } \\
\text { managerial mindset }\end{array}$ \\
\hline
\end{tabular}


Table 3. continued

\begin{tabular}{|c|c|c|c|c|c|}
\hline Authors & Title & Research question & $\begin{array}{l}\text { How the article } \\
\text { relates to the LTE } \\
\text { transition } \\
\text { framework } \\
\text { (Figure 1) }\end{array}$ & Data source(s) & $\begin{array}{l}\text { How the article } \\
\text { contributes to research } \\
\text { on the LTE transition }\end{array}$ \\
\hline $\begin{array}{l}\text { Nippa, } \\
\text { Patnaik \& } \\
\text { Taussig }\end{array}$ & $\begin{array}{l}\text { MNE responses to } \\
\text { carbon pricing } \\
\text { regulations: Theory and } \\
\text { evidence }\end{array}$ & $\begin{array}{l}\text { How do MNEs differ } \\
\text { from domestic firms } \\
\text { in their responses to } \\
\text { international } \\
\text { regulatory initiatives? }\end{array}$ & $\begin{array}{l}\text { Emphasizes } \\
\text { regulatory } \\
\text { drivers } \\
\text { Analyzes the } \\
\text { influence of } \\
\text { firm-level } \\
\text { capabilities } \\
\text { and temporal } \\
\text { dynamics } \\
\text { Shows the } \\
\text { relationship } \\
\text { between } \\
\text { regulation and } \\
\text { environmental } \\
\text { sustainability }\end{array}$ & $\begin{array}{l}\text { EU emissions trading } \\
\text { schemes and carbon } \\
\text { tax schemes }\end{array}$ & $\begin{array}{l}\text { Shows empirically how } \\
\text { MNEs can act as drivers } \\
\text { of the LTE transition } \\
\text { Argues that FSAs must } \\
\text { be nuanced in order to } \\
\text { fully understand the } \\
\text { role of the MNE in LTE } \\
\text { transition } \\
\text { Shows the impact of } \\
\text { regulation may be } \\
\text { more nuanced than it } \\
\text { may appear } \\
\text { Argues that IB research } \\
\text { needs to consider } \\
\text { temporal dynamics to } \\
\text { understand the LTE } \\
\text { transition }\end{array}$ \\
\hline $\begin{array}{l}\text { Patala, } \\
\text { Juntunen, } \\
\text { Lundan \& } \\
\text { Ritvala }\end{array}$ & $\begin{array}{l}\text { Multinational energy } \\
\text { utilities in the energy } \\
\text { transition: A } \\
\text { configurational study of } \\
\text { the drivers of FDI in } \\
\text { renewables }\end{array}$ & $\begin{array}{l}\text { Which combinations } \\
\text { of firm and host- } \\
\text { country conditions } \\
\text { lead to FDI in } \\
\text { renewable energy? }\end{array}$ & $\begin{array}{l}\text { Investigates } \\
\text { economic and } \\
\text { regulatory } \\
\text { drivers of } \\
\text { investment in } \\
\text { renewable } \\
\text { energy } \\
\text { Discusses firm- } \\
\text { level } \\
\text { capabilities } \\
\text { Stresses } \\
\text { investment in } \\
\text { renewable } \\
\text { energy } \\
\text { solutions } \\
\text { Discusses FDI }\end{array}$ & $\begin{array}{l}289 \text { greenfield } \\
\text { investments by } 17 \\
\text { multinational energy } \\
\text { utilities }\end{array}$ & $\begin{array}{l}\text { Provides a } \\
\text { configurational analysis } \\
\text { that shows how even } \\
\text { within the same firm, } \\
\text { decisions may } \\
\text { contribute to a "race to } \\
\text { the top" as well as a } \\
\text { "race to the bottom" } \\
\text { depending on the } \\
\text { interplay of FSAs and } \\
\text { CSAs }\end{array}$ \\
\hline $\begin{array}{l}\text { Doh, } \\
\text { Budhwar \& } \\
\text { Wood }\end{array}$ & $\begin{array}{l}\text { Long-term energy } \\
\text { transitions and } \\
\text { international business: } \\
\text { Concepts, theory, } \\
\text { methods, and a research } \\
\text { agenda }\end{array}$ & $\begin{array}{l}\text { What are the } \\
\text { challenges the LTE } \\
\text { transition poses and } \\
\text { how can these be } \\
\text { conceptualized and } \\
\text { answered by IB } \\
\text { scholars? }\end{array}$ & $\begin{array}{l}\text { Discusses } \\
\text { economic, } \\
\text { social, } \\
\text { technological, } \\
\text { and regulatory } \\
\text { drivers } \\
\text { Explores firm- } \\
\text { level } \\
\text { capabilities } \\
\text { and temporal } \\
\text { dynamics } \\
\text { Analyzes energy } \\
\text { solutions }\end{array}$ & - & $\begin{array}{l}\text { Stimulates a dialogue on } \\
\text { how IB and international } \\
\text { management scholars } \\
\text { can study the LTE } \\
\text { transition and other } \\
\text { multi-level, multi-actor } \\
\text { phenomena }\end{array}$ \\
\hline
\end{tabular}


LTE transition provides a fruitful avenue for understanding the role of the MNE in contributing to environmental sustainability by employing strategies that reduce emissions. However, our conceptual framework also points to the need for more research on challenges related to energy security and accessibility.

As the contributors show, studies of the LTE transition also require methods that can capture the complex relationships and interdependencies of multilevel variables. This pushes IB scholars to rethink theoretical perspectives and methodological choices. In particular, the article by Doh et al. sheds light on the importance of capturing the complexities of multi-level and multi-actor interdependencies, putting forth important theoretical and methodological considerations to develop a research agenda on the LTE transition.

Finally, each of the articles tackles one or more important facets of the LTE transition while advancing IB scholarship. Our review of them highlights the strengths of IB research, particularly for understanding how LTE transition drivers shape MNE strategies but also how MNE strategies shape the LTE transition. It also makes clear that more IB work needs to be done. For example, although environmental sustainability is of importance for the LTE transition, those conducting research on other relevant outcomes, including energy security and energy accessibility, could benefit from IB theorizing.

\section{CONCLUDING REMARKS}

The long-term energy transition exemplifies the global shift away from the production and consumption of nonrenewable fossil fuels towards the use of low-carbon and renewable energy sources, and is genuinely of earthshaking importance. It also provides an ideal context for furthering our understanding of a variety of phenomena that can be addressed with IB theory - such as power dynamics and changing interdependencies - as the nonrenewables on which our global community has long relied are being supplanted by lowcarbon and renewable energy solutions. The LTE transition is also bringing about changes in stakeholder relationships. MNEs, and not only those producing energy, must develop new capabilities to remain competitive. Adaptation is inevitable for MNEs in many industries, as manufacturing, construction, high-tech, and many others are directly impacted by the LTE transition. It is imperative that MNEs adapt their existing business models or develop new ones to be in step with the move away from nonrenewables to lowcarbon and renewable energy solutions. Along with the challenges that MNEs face, there are opportunities. MNEs can be successful by helping to solve the energy accessibility problems that have plagued so many for so long. They can provide countries and communities that have been hobbled by a lack of nonrenewable energy infrastructures with viable renewable energy solutions. Doing so is not always straightforward. The "new" global landscape goes hand-in-hand with a new institutional environment that consists of sometimes vastly different regulations, creating complexities for MNEs that operate in multiple institutional contexts.

The LTE transition provides fertile ground for researchers interested in how MNEs both influence and are being influenced by changes in the global energy system. It can shed light on the dynamics of CSA and FSA recombination and provide useful advice to MNE managers that navigate in a VUCA world, just as a better understanding of the key economic, social, technological, and regulatory drivers of the LTE transition can help them craft better strategies and business models. Such insights can also be useful to policymakers seeking to facilitate the LTE transition. We trust that the articles in this special issue will stimulate still more research interest in "The Grand Challenge of Energy Transitions".

\section{ACKNOWLEDGEMENTS}

We would like to thank Editor in Chief Alain Verbeke for constructive feedback on an early draft of this article and Managing Editor Anne Hoekman for guidance throughout this process. The attendees of the professional development workshop for the special joint Journal of International Business Studies/British 
Management Journal initiative on Long-Term Energy Transitions provided valuable insights and inspiration to write this editorial.

\section{NOTES}

${ }^{1}$ The Kyoto Protocol commits industrialized countries to reductions in greenhouse gas emissions and serves as a benchmark for global environmental sustainability progress.

Devinney, T. M., Mcgahan, A. M., \& Zollo, M. 2013. A research agenda for global stakeholder strategy. Global Strategy Journal, 3(4): 325-337.

Doh, J. P. 2019. MNEs, FDI, inequality and growth. Multinational Business Review, 27(3): 217-220.

Dunford, R. 1987. The suppression of technology as a strategy for controlling resource dependence. Administrative Science Quarterly, 32(4): 512-525.

Eavor. 2020. Technology. https://eavor.com/about/technology. Accessed 8 Jan 2021.

Eskeland, G. S., \& Harrison, A. E. 2003. Moving to greener pastures? Multinationals and the pollution haven hypothesis. Journal of Development Economics, 70(1): 1-23.

Feiler, P., \& Teece, D. 2014. Case study, dynamic capabilities and upstream strategy: Supermajor EXP. Energy Strategy Reviews, 3: 14-20.

Finley, M. 2019. Energy security and the energy transition: A classic framework for a new challenge. Baker Institute Report No. 11.25.19. Rice University's Baker Institute for Public Policy, Houston, Texas. https://doi.org/10.25613/DWEPY289.

Freeman, R. E. 1984 Strategic management: A stakeholder approach. Cambridge University Press.

Georgallis, P., Dowell, G., \& Durand, R. 2019. Shine on me: Industry coherence and policy support for emerging industries. Administrative Science Quarterly, 64(3): 503-541.

Girish, G. P., Sashikala, P., Supra, B., \& Acharya, A. 2015. Renewable energy certificate trading through power exchanges in India. International Journal of Energy Economics and Policy, 5(3): 805-808.

Grøgaard, B., Colman, H. L., \& Stensaker, I. G. 2019. Legitimizing, leveraging, and launching: Developing dynamic capabilities in the MNE. Journal of International Business Studies. https://doi.org/10.1057/s41267-019-00245-5.

Grøgaard, B., Rygh, A., \& Benito, G. R. G. 2019. Bringing corporate governance into internalization theory: State ownership and foreign entry strategies. Journal of International Business Studies, 50(8): 1310-1337.

Hallbäck, J., \& Gabrielsson, P. 2013. Entrepreneurial marketing strategies during the growth of international new ventures originating in small and open economies. International Business Review, 22(6): 1008-1020.

Heikell, L. 2020. Northern Lights is innovating for the future of carbon transport and storage. Microsoft. https://news. microsoft.com/transform/northern-lights-is-innovating-forthe-future-of-carbon-transport-and-storage/. Accessed $21 \mathrm{Nov}$ 2020.

Hovland, K. M. 2020. Tangen mener fornybar energi er dyrt: Det er mange om beinet. E24. https://e24.no/den-groenneoekonomien/i/pAArER/tangen-mener-fornybar-energi-er-dyrtdet-er-mange-om-beinet. Accessed 8 Dec 2020.

IEA. 2020a. Tracking clean energy progress. https://www.iea. org/topics/tracking-clean-energy-progress. Accessed $10 \mathrm{Nov}$ 2020.

IEA. 2020b. The oil and gas industry in energy transitions. https://www.iea.org/reports/the-oil-and-gas-industry-inenergy-transitions. Accessed 10 Nov 2020. 
IEA. 2020c. Fuels and technologies. https://www.iea.org/fuelsand-technologies. Accessed 10 Nov 2020.

IEEFA. 2019. Facebook makes first direct investment in renewable energy project. Institute for Energy Economics and Financial Analysis. https://ieefa.org/facebook-makes-first-directinvestment-in-renewable-energy-project/. Accessed 14 Jan 2021.

Deloitte Insights. 2020. Navigating the energy transition from disruption to growth. https://www2.deloitte.com/us/en/ pages/about-deloitte/articles/press-releases/navigatingenergy-transition-disruption-growth.html. Accessed 14 Mar 2021.

Island Green Power. 2021. Our projects. https://islandgp.com/ our-projects/. Accessed 21 Jan 2021.

Jen, S. 2007. Sovereign wealth funds. World Economics, 8(4): $1-7$.

Kaenzig, J., Heinzle, S. L., \& Wüstenhagen, R. 2013. Whatever the customer wants, the customer gets? Exploring the gap between consumer preferences and default electricity products in Germany. Energy Policy, 53: 311-322.

Kelly-Detwiler, P. 2019. Solar technology will just keep getting better: Here's why. Forbes. https://www.forbes.com/sites/ peterdetwiler/2019/09/26/solar-technology-will-just-keepgetting-better-heres-why/?sh=40fbf16d7c6b. Accessed 14 Oct 2020.

Kuhlman, T., \& Farrington, J. 2010. What is sustainability? Sustainability, 2(11): 3436-3448.

Lawrence, T. B., Leca, B., \& Zilber, T. B. 2013. Institutional work: Current research, new directions and overlooked issues. Organization Studies, 34(8): 1023-1033.

London, T., \& Hart, S. L. 2004. Reinventing strategies for emerging markets: Beyond the transnational model. Journal of International Business Studies, 35(5): 350-370.

Luo, Y. 2000. Dynamic capabilities in international expansion. Journal of World Business, 35(4): 355-378.

Marcus, A., Malen, J., \& Ellis, S. 2013. The promise and pitfalls of venture capital as an asset class for clean energy investment: Research questions for organization and natural environment scholars. Organization \& Environment, 26(1): 31-60.

Mbalyohere, C., Lawton, T., Boojihawon, R., \& Viney, H. 2017. Corporate political activity and location-based advantage: MNE responses to institutional transformation in Uganda's electricity industry. Journal of World Business, 52(6): 743-759.

Meyer, K. E. 2004. Perspectives on multinational enterprises in emerging economies. Journal of International Business Studies, 35(4): 259-276

Miller, C. A., lles, A., \& Jones, C. F. 2013. The social dimensions of energy transitions. Science as Culture, 22(2): 135-148.

Mohr, A., Wang, C., \& Fastoso, F. 2016. The contingent effect of state participation on the dissolution of international joint ventures: A resource dependence approach. Journal of International Business Studies, 47(4): 408-426.

Narula, R., Asmussen, C. G., Chi, T., \& Kundu, S. K. 2019. Applying and advancing internalization theory: The multinational enterprise in the twenty-first century. Journal of International Business Studies, 50(8): 1231-1252.

Natural Resources Canada. 2020. About renewable energy. Government of Canada. Accessed 8 Dec 2020.

New Climate Institute. 2020. Climate action tracker. https:// climateactiontracker.org/countries/. Accessed 21 Jan 2021.

Norges Bank. 2020. Strategy plan 2020-2022. https://www. nbim.no/no/publikasjoner/strategi-for-fondets-forvaltning/ strategiplan-2020-2022/. Accessed 22 Dec 2020.

Onsongo, E. 2019. Institutional entrepreneurship and social innovation at the base of the pyramid: The case of M-Pesa in Kenya. Industry and Innovation, 26(4): 369-390.

Ørsted. 2020. Generation and operations. https://orsted.com/ en/sustainability/climate-action-plan/generation-andoperations. Accessed 8 Nov 2020.
Park, B. I., Chidlow, A., \& Choi, J. 2014. Corporate social responsibility: Stakeholders influence on MNEs' activities. International Business Review, 23(5): 966-980.

Ramirez, J. 2021. Governance in energy democracy for Sustainable Development Goals: Challenges and opportunities for partnerships at the Isthmus of Tehuantepec. Journal of International Business Policy, 4(1): 119-135.

Ratinen, M., \& Lund, P. 2015. Policy inclusiveness and niche development: Examples from wind energy and photovoltaics in Denmark, Germany, Finland, and Spain. Energy Research \& Social Science, 6: 136-145.

Ritchie, H., \& Roser, M. 2020. CO2 Emissions. OurWorldInData.org. https://ourworldindata.org/co2-emissions. Accessed 19 Jan 2021.

Riviere, M., Bass, A. E., \& Andersson, U. 2020. Dynamic capability development in multinational enterprises: Reconciling routine reconfiguration between the headquarters and subsidiaries. Global Strategy Journal, advance online publication July 31. https://doi.org/10.1002/gsj.1389.

Rossignoli, F., \& Lionzo, A. 2018. Network impact on business models for sustainability: Case study in the energy sector. Journal of Cleaner Production, 182: 694-704.

Rugman, A. M., \& Verbeke, A. 1998. Corporate strategies and environmental regulations: An organizing framework. Strategic Management Journal, 19(4): 363-375.

Rugman, A. M., \& Verbeke, A. 2001. Subsidiary-specific advantages in multinational enterprises. Strategic Management Journal, 22(3): 237-250.

S\&P Global. 2020. What is energy transition? https://www. spglobal.com/en/research-insights/articles/what-is-energy-tra nsition. Accessed 18 Nov 2020.

Schiermeier, Q. 2020. The US has left the Paris climate dealWhat's next? Nature. https://www.nature.com/articles/ d41586-020-03066-x. Accessed 8 December 2020.

Shakeel, S. R., Takala, J., \& Zhu, L.-D. 2017. Commercialization of renewable energy technologies: A ladder building approach. Renewable and Sustainable Energy Reviews, 78: 855-867.

Shapiro, D., Hobdari, B., \& Oh, C. H. 2018. Natural resources, multinational enterprises and sustainable development. Journal of World Business, 53(1): 1-14.

Shead, S. L. 2020. Facebook to use artificial intelligence in bid to improve renewable energy storage. CNBC. https://www.cnbc. com/2020/10/14/facebook-to-use-ai-in-bid-to-improverenewable-energy-storage.html. Accessed 11 Jan 2021.

Shuen, A., Feiler, P. F., \& Teece, D. J. 2014. Dynamic capabilities in the upstream oil and gas sector: Managing next generation competition. Energy Strategy Reviews, 3: 5-13.

Sovacool, B. K. 2016. How long will it take? Conceptualizing the temporal dynamics of energy transitions. Energy Research \& Social Science, 13: 202-215.

Sovacool, B. K., \& Drupady, I. M. 2016. Energy access, poverty, and development: The governance of small-scale renewable energy in developing Asia. Abingdon: Routledge.

Stegen, K. S., Gilmartin, P., \& Carlucci, J. 2012. Terrorists versus the sun: Desertec in North Africa as a case study for assessing risks to energy infrastructure. Risk Management, 14(1): 3-26.

Teece, D. J. 2014. A dynamic capabilities-based entrepreneurial theory of the multinational enterprise. Journal of International Business Studies, 45(1): 8-37.

van Tulder, R., Verbeke, A., \& Jankowska, B. 2019. International business in a VUCA world: The changing role of states and firms. Bingley: Emerald.

Vera, I., \& Langlois, L. 2007. Energy indicators for sustainable development. Energy, 32(6): 875-882.

Verbeke, A., \& Kano, L. 2016. An internalization theory perspective on the global and regional strategies of multinational enterprises. Journal of World Business, 51(1): 83-92.

Verbeke, A., Osiyevskyy, O., \& Backman, C. A. 2017. Strategic responses to imposed innovation projects: The case of carbon 
capture and storage in the Alberta oil sands industry. Long Range Planning, 50(5): 684-698.

World Bank. 2020. World Bank Data. https://data.worldbank. org/. Accessed 2 Nov 2020.

Zeng, X., Li, J., \& Liu, L. 2015. Solving spent lithium-ion battery problems in China: Opportunities and challenges. Renewable and Sustainable Energy Reviews, 52: 1759-1767.

Zinaman, O., Miller, M., Adil, A., Arent, D., Cochran, J., Vora, R., Aggarwal, S., Bipath, M., Linvill, D. A., Futch, M., Kaufman, R., Arcos, E. V., Valenzuela, J. M., Martinot, E., Noll, D., Bazilian, M., \& Pillai, R. K. 2015. Power systems of the future. The Electricity Journal, 28(2): 113-126.

\section{ABOUT THE AUTHORS}

A. Erin Bass is an Associate Professor of Management at the University of Nebraska Omaha, USA. Her research centers on resource and capability development and deployment in firms, corporate social responsibility, and stakeholder management.
She is particularly interested in these concepts in the context of the energy industry. Erin has professional experience in the energy and non-profit sectors.

Birgitte Grøgaard is a Professor in the Department of Strategy and Entrepreneurship at BI Norwegian Business School, Oslo, Norway. Her research interests include strategies of multinational enterprises, headquarter-subsidiary relationships, and foreign direct investments. Birgitte's research is currently focused on how firms develop organizational flexibility to address energy transition challenges. Prior to pursuing her PhD, Birgitte worked for a multinational oil and gas company.

Publisher's Note Springer Nature remains neutral with regard to jurisdictional claims in published maps and institutional affiliations.

Accepted by Alain Verbeke, Editor-in-Chief, 19 March 2021. This article has been with the authors for one revision and was single-blind reviewed. 